\title{
'Laboratorio Q', Seville: creative production of collective spaces before and after austerity
}

María F. Carrascal ${ }^{1}$, Pablo Sendra ${ }^{2}$, Plácido González Martínez ${ }^{3}$, Antonio

Alanís Arroyo $^{1}$, Alfonso Guajardo ${ }^{1}$, Carlos García Vázquez ${ }^{1}$

${ }^{1}$ Instituto Universitario de Arquitectura y Ciencias de la Construcción, Universidad de

Sevilla, Seville, Spain; ${ }^{2}$ The Bartlett School of Planning, University College London,

London, UK, ${ }^{3}$ College of Architecture and Urban Planning, Tongji University,

Shanghai, China.

Paper accepted in Journal of Urbanism: International Research on Placemaking and Urban Sustainability. Please reference as:

Carrascal, M F; Sendra, P; González Martínez, P; Alanís Arroyo, A; Guajardo, A; García Vázquez, C. (Forthcoming) 'Laboratorio Q', Seville: creative production of collective spaces before and after austerity'. Journal of Urbanism: International Research on Placemaking and Urban Sustainability.

Correspondence author:

Carlos García Vázquez: ccggvv@us.es

Escuela Técnica Superior de Arquitectura

Avda. Reina Mercedes 2

41012 Sevilla (Spain)

María F. Carrascal is a PhD Architect with international mention and, since 2011, teaches at the Department of Architectural History, Theory and Composition of the Universidad de Sevilla. She also is adjunct professor at the Department of Art and Design in the European program of St. John's University. Her research field focuses in the relationship between art/creativity and city developed in the European and American context from the second half of the XX Century. 
Pablo Sendra is Lecturer in Planning and Urban Design at The Bartlett School of Planning, University College London. He has a $\mathrm{PhD}$ in Architecture from the Universidad de Sevilla. $\mathrm{He}$ is co-founder of Lugadero, an urban design and placemaking practice. Both his academic research and professional activity focus on collaborative practices for designing public spaces. His work has been published in international journals and received awards.

Plácido González Martínez is a Ph.D. Architect and urban planner, associate professor at the College of Architecture and Urban Planning of Tongji University, Shanghai, and executive editor of the Built Heritage Journal. His research focuses in contemporary and modern built heritage, with a special insight into the issues of authenticity, creative cities and the historic urban landscape.

$\mathrm{PhD}$ candidate at Universidad de Sevilla (2013-) and MSc in Sustainable City and Architecture. $\mathrm{He}$ is a researcher at the "Contemporary City, Architecture and Heritage" PAI-HUM-666 Group where he is involved in the line of investigation called "Urban Obsolescence: Neighbourhood, Public Space and Productive Areas" throughout projects developed by Laboratorio Q and the Manual of Best Practices for Intervention on Obsolete Residential Neighbourhoods (funded by Junta de Andalucia and European Union).

Alfonso Guajardo is a PhD candidate at the Universidad de Sevilla and MSc in Sustainable City and Architecture (2013). His research focuses in housing typologies as one of the main reasons for the current obsolescence of the residential neighbourhoods built in Spain between 1950 and 1980. He is involved in Laboratorio Q since 2014.

Carlos García Vázquez: Architect, Full Professor in the Escuela Tecnica Superior de Arquitectura de Sevilla, Visiting Professor in the Politecnico di Milano. Author of the books: "Teorias e historia de la ciudad contemporanea" (Gustavo Gili, 2016) and "Ciudad Hojaldre. Visiones urbanas del siglo XXI" (Gustavo Gili, 2004). 


\section{'Laboratorio Q', Seville: creative production of collective spaces before and after austerity}

The creative city approach is going through a redefinition after the 2008 global financial crisis. In the specific case of South-European cities, in the context of austerity and cuts in public investment, creativity is becoming a strategy for achieving maximum social benefit and improvement of the built environment with minimum economic expenditure. This paper looks at this redefinition of creativity through the case study of Seville, in southern Spain. Through research methods that include video-recorded testimonies of the actors involved, mapping at the online platform 'Laboratorio Q', and public engagement activities, this paper explores how the civic society, professional, and public authorities have reinvented how to produce collective spaces. The paper concludes that bottom-up creative processes for producing collective spaces have become more visible since the 2008 crisis, when architects, planners, public authorities and policymakers have been 'learning' from them.

Keywords: creative city; bottom-up; public space; Seville; collective space; austerity

\section{Introduction}

Creative city-making was seen at the turn of the $21^{\text {st }}$ century as a marketing strategy for cities to attract human capital (Landry, 2000; Florida, 2002), enabling the attraction of investment in the knowledge and cultural sectors. Cities adopted strategies for the improvement of the built environment and the production of a comfortable atmosphere for the 'creative class' (Florida, 2002) through speculative projects that included the work of renowned 'starchitects' and the provision of sophisticated infrastructures. This creative-city euphoria took place in a context of pre-2008 economic growth, associated in some cases with real estate development.

After the 2008 credit crunch, this context changed, particularly in South European cities, which went through austerity measures and severe cuts in public services. Creativity has thus radically transformed its definition, moving from being a 
source for economic development to becoming a source for survival (see Arampatzi, 2017). Public authorities, community groups, civic entrepreneurs and different kinds of organisations have used this renovated concept to minimize the amount of resources and achieve the maximum degree of lasting transformations. Public authorities have seen this as an opportunity to spend less resources and design programmes that demand a higher involvement of the civil society (McKee, 2015) to self-organise to create collective spaces (see Finn 2014a), to organise cultural activities or to cooperate to find new business models.

Given this change of approach in the provision of creative places and the forms of self-organisation adopted by civil society to provide collective spaces, this paper aims to address the following questions: Have alternative options for the production of creative spaces emerged in the context of austerity? Has the role of public authorities in enabling these initiatives changed? Have planners and architects learned from these experiences?

To answer these questions this paper uses the case study of the city of Seville, a city that developed some good public infrastructure as well as high-budget 'spectacle architecture' during the 2000s and which has suffered the consequences of austerity. Looking at a variety of initiatives that appeared both before and after the 2008 global financial crisis, it will explain how citizen collectives, community groups, designers, local authorities and cultural institutions have used and produced collective spaces in a context of low expenditure. To do so, this research first provides a context of the urban strategies adopted by the municipality at the turn of the 21 st century and then analyses case studies of alternative ways of producing collective spaces, exploring the role of public authorities, community groups, architects and planners in the production of these spaces. For the analysis of case studies, it uses video-recorded testimonies with the main 
actors in the production of these spaces: public authorities, activists, architects, and community groups. It also uses a mapping tool on an online platform to bring these experiences together and civic engagement events to involve the participants in the production of knowledge.

\section{Seville as a case study}

Seville is a city with a population of 693,878 inhabitants $(1,533,230$ in the whole metropolitan area) $)^{1}$, whose recent history shows the extent of both approaches to creativity: top-down, inspired by global models and based on strong budgets; and bottom-up , inspired by local models and executed with modest budgets. Both approaches developed in parallel in the decade before the 2008 crisis, although the former was defined and tested before, between 1982, when the Bureau International des Expositions (BIE) approved the celebration in Seville of a World Fair, and 1992, when it was inaugurated. We will start by presenting this top-down transformation of the city before going on to examine the bottom-up one.

The origin of the contemporary urban image of Seville was the World Exhibition of 1992, located in Cartuja Island, next to the historic city centre. Together with the Barcelona Olympics, the Exhibition was the kick-off for a strong and sustained process of economic growth which lasted over a decade before coming to an abrupt end in 2008. As a result of this process, the country saw a huge transformation in the built environment, placing Spanish architecture and urbanism in one of the most avant-garde positions in the world, as showcased in the exhibition "On-Site: New Architecture in Spain” at the New York MoMa in 2006 (Riley and Fernández-Galiano 2006).

In the case of Seville, the World Exhibition required the adoption of a sort of global and urban development model. It was not one directed by neoliberal economic 
needs alone as the public administration played an important role in developing architectural and city planning strategies that provided public spaces and infrastructure to improve the life of Seville residents. This global urban model, supported by spectacular budgets, was a characteristic 'official' top-down transformation process founded on three pillars: the support of mass transit systems, the defence of public space, and the use of 'spectacle architecture' as an urban regeneration strategy.

Regarding the first issue, most urban strategies planned for the 1992 Expo prioritised private transport, giving rise to severe problems of traffic congestion at the turn of the 21 st century. Seville coped with this on two different scales: the metropolitan and the urban one. In the case of the former, the first underground line was builtalthough it was not completed for several years-, crossing the city East to West and connecting it with its surrounding areas, bringing about a sharp reduction in commuting time. In the case of the urban scale, a 171-kilometre-long network of bike lanes was designed and built, together with a bike rental system with 260 stations and 2600 bicycles. This led to a significant transformation of the city, with 68,000 people using the system on a daily basis, changing the atmosphere and the tone of the urban space (Valdés Aragonés 2014).

The transformation of public spaces has focused on prioritising pedestrians over cars. The two most important cultural and commercial axes of the city prioritised people. In the southern half of the historic centre, San Fernando Street and Constitución Avenue (figure 1), the site of the most important monuments of Seville (the old Tobacco Factory, the Indies Archive, the Cathedral, and the City Hall), were transformed into an area where pedestrians share the space with a new tram service and occasional photography exhibitions. In the northern half of the historic district, the Alameda de Hércules was renewed by the architects Martínez Lapeña and Torres Tur. 
Vehicular traffic was limited to the edge, the whole space was continuously paved in continuity, the vegetation was recovered, and new urban furniture was installed. The redesign of the Alameda de Hércules in 2006 has become the symbol of the transformation of the northern side of the historic centre, known as Casco Norte, which began in the 1990s and is still ongoing. Traditionally a place of creativity and resistance, as shown in the book El Gran Pollo de la Alameda (Barber et al. 2006), this neighbourhood has undergone a process of gentrification which has brought improvements to public spaces. This has also led to a process of real estate speculation and a major challenge to the residents of the historic centre, who have witnessed their neighbourhood being transformed into a retail and hostelry area.

The third point of this global urban model, the use of 'spectacle architecture' as an urban regeneration tool, has been a common strategy in many other European cities since the 1990s, commissioning architects to design high-budget buildings that would transform the image to the city. In the case of Seville, its first initiative of 'spectacular architecture' is located at the heart of the historic area: the Plaza de la Encarnación. Jürgen Mayer's “Metropol Parasol” proposal, winner of the international competition, consists of six massive mushroom-like connected structures which are meant to provide shade in Seville hot summers, and claims to be "one of the largest and most innovative bonded timber-constructions" (http://www.jmayerh.de/19-0-metropol-parasol.html, n.d, accessed 5 October 2017). The functional content of the site is very complex: an archaeological site in the basement, a market on the ground floor, a public square on the first floor, and restaurants and an observatory at the top. The competition took place in 2004 and the construction work began in 2005. It came up against several issuesincluding an interruption of the works and a substantial increase in costs (Rincón 
2010) - and the project was not finished until March 2011, when Spain was already suffering the consequences of the economic crisis ${ }^{2}$.

The second 'spectacle building' is the first skyscraper in the city (figure 2). The Torre Sevilla, designed by César Pelli, was placed by the west gate of the city, that closest to the historic centre, but on the opposite riverbank. Its 180 metres doubled the height of the Giralda, the cathedral bell tower built in 1198 as an Islamic minaret, and main icon of the city. As a result, Torre Sevilla has radically changed the urban skyline and the relationship of the city with the landscape of the Guadalquivir Valley, to the point of causing conflict with the UNESCO World Heritage Committee, which threatened with adding Seville's historic centre to the list of endangered heritage due to the impact of the tower, although this finally did not happen (Rincón 2012).

In 2008, the crisis hit Spain with devastating effects: unemployment rates rose to $26.94 \%$ of the population ${ }^{3}$; the real estate bubble burst with a dramatic drop of $40 \%$ in housing prices ${ }^{4}$; salaries decreased and taxes were increased. This resulted in a reduction of the middle class and an increase in poverty rates; with soaring public and private debt forcing the government to apply severe cuts in crucial social services, such as education and healthcare.

In light of the global urban transformation model mentioned above, an important consideration arises concerning costs. The city council paid 102 million euros for the Plaza de la Encarnación (Barba 2012), while the Torre Sevilla, owned by a bank, cost 325 million euros ${ }^{5}$; and the regional government paid 658 million euros for the underground line ${ }^{6}$. In contrast, the city council paid only 35 million euros for the network of bike lanes ${ }^{7}$, which was the project with the greatest impact on the everyday life of the citizens (Brey et al. 2017). This leads to a reflection on whether it is truly 
necessary to spend such high amounts of money to change our cities or whether there is another way to do it.

Our research aims to provide answers to this reflection. As we said, in parallel with the aforementioned top-down transformation process, alternative kinds of bottomup transformations have been taking place in the city during the same years. They have been inspired by local models, carried out with modest budgets, and based on a concept of creativity understood as responding to everyday needs with unexpected proposals. The case studies analysed below explore these alternative urban transformations before and after the global financial crisis.

\section{Methodology}

In order to address the research questions, this paper explores cases studies in Seville, using a methodology that involves participants in the production of knowledge: through video-recorded testimonies from activists, community groups and architects involved in creative transformations of common spaces, as well as from public authorities that developed or enabled this kind of transformation. In addition to these accounts, a mapping tool was produced where anyone can upload 'creative places' and public engagement events to involve participants, community groups and activists in the research. The research project Laboratorio Q studies a specific period of time- between 1996 and 2012.

\section{Delimiting the period of study}

Given the specific characteristics of the socio-economic context of South-European cities, this research has chosen a study time-span that includes both the period of maximum expenditure in urban developments and the period of minimal investment in the improvement of public spaces and cuts on cultural programmes. The first period is 
that from 1996 to 2007, which starts with the advent of the 1992 crisis - particularly strong in Seville after all the investment in the 1992 Expo-and the coming to power of the conservative Partido Popular in the national government, who introduced liberalization measures into the Land Use legislation, allowing for massive urbanization as well as fostering real estate development. The second period spans 2008 to 2012, starting with the global financial crisis, when the unemployment rate reached over $35 \%$ in the region of Andalusia (INE, 2013) and there were severe cuts in public services (Garea, 2012).

\section{Data collection: testimonies from the actors involved}

In the period between 1996 and 2012, creative urban actions took place in Seville, both from the bottom-up - from local communities, activists, creative groups and civic entrepreneurs - and from the top-down — cultural institutions such as the local government or the Andalusian Centre of Contemporary Art. Given the diverse nature of these actions, it is necessary to apply a research methodology that collects testimonies both from grassroots organisations and from public authorities involved in these actions.

Due to their recentness and their grassroots nature, these initiatives have had very little impact on academic literature or other channels of dissemination of urban practices (Alanís et al. 2015). In some cases, they were hidden practices that were hard to find. This has meant that the methodology has used the testimonies from local community groups and activists as the primary source of knowledge.

The research methodology for collecting testimonies consisted in the following:

(1) Preliminary desktop research on newspapers, publications, blogs and websites developed by community groups in order to select the case studies, interviewees, and prepare the interviews. 
(2) Interviews and video-recorded testimonies. Once a preliminary selection of creative initiatives was identified through desktop inquiry, the interview process began. The aim was to collect testimonies from a representative selection of voices among identified stakeholders: members of neighbourhood associations, activists, creative professionals, researchers, and institutional representatives (figure 3). The one-hour tape-recorded in-depth semi-structured interviews were followed by a five-minute video-recorded testimony, which would then be incorporated into an online archive of testimonies associated with the 'creative places' mapped (see González et al. 2017). The interview was divided into four topics: the first one had a set of questions about the context of the period of study, examining how urban creativity had evolved in this time period. The second aimed to identify the urban interventions, asking the interviewees about those that they were aware of and about potential contacts for more interviews, thus directly involving participants in the selection of case studies and reconstructing the history of bottom-up initiatives in Seville (see Alanís et al. 2015). The third set of questions examined the impact of these interventions in the city. Finally, the fourth asked the interviewees to reflect on the relevance of academic research about these creative urban practices and the visualisation of local knowledge through mapping the actions in an online platform. These interviews were tailored to the interviewees, including:

(a) Activists, community groups and creative collectives directly involved in the bottom-up transformations ${ }^{8}$ : In those cases, the interviews were carried out on site $^{9}$, and included a guided visit by the participants involved in the action, focusing on the case study as well as the identification of other cases. The questions were modified slightly to suit individual contexts and interviewees. 
The output from these interviews was a collection of local knowledge from those involved in the urban actions.

(b) Academics, architects, creative practitioners and curators who had studied these creative transformations, and in some cases were involved in activism or urban actions ${ }^{10}$. These interviews were particularly helpful in identifying more cases and research gaps.

(c) Representatives of public institutions ${ }^{11}$ : These interviews helped to identify the approach of public authorities in enabling and promoting creative processes in the public space.

(3) Contrasting the outputs of the interviews. Once these sources of local knowledge about the actions were collected, the next step was to contrast the information provided with other available sources: printed and online newspapers, blogs or websites developed by local people, architects or members of the creative community involved in the actions, online videos, publications and catalogues on artistic interventions in the city, books, articles in art and architecture journals and cultural magazines. This helped to provide additional evidence of the actions and to explore possible conflictive situations which may not have been revealed in the interviews.

(4) Mapping: The creative places identified were mapped on the online platform www.laboratorioq.com and tags were assigned according to their time and spatial characteristics (Figure 4).

\section{Public engagement: participatory mapping, co-production of knowledge and events}

In order to find and register both bottom-up and top-down creative initiatives, Laboratorio Q used research methods to involve the participants in the production of knowledge. These methods included: 
(1) Participatory mapping: Laboratorio Q incorporated a participatory mapping tool in its online platform, making it possible for anyone to introduce a new project. These collaborative entries were moderated by the members of the research group before publication, to ensure their agreement with the research criteria and to validate the information standards and content. The projects identified, mapped and described by the public were tagged as "suggested"12. In this way, the research enabled transferability between public participation and research and called for the collective construction of an archive of creative urban initiatives.

(2) Involvement of participants in the production of knowledge: the interviews included questions that helped the researchers to identify urban actions that could not be found in the preliminary research and to reconstruct the story that led to their creation, who was involved, and the impact they had. Questions were also included regarding the usefulness of this platform to community groups, activists, collectives and people involved in these processes, and the feedback gathered was taken into account when designing the platform. In addition to this, the video-recorded testimonies created an online archive in which the participants tell the story of the creative places.

(3) Public engagement events: the results from the information collected in the interviews were shared with the participants and with the public in two engagement events. The first of these was the launch of the platform, organised by Laboratorio Q in Tramallol (figure 5), one of these creative places recorded, and with some of the participants both in attendance and as guest speakers. This event transformed into an intense debate on the role of academic research in bottom-up processes. The second presentation of Laboratorio Q was at the 'Encuentro de Arquitecturas Colectivas', an annual meeting of a national network of collectives that develop bottom-up urban 
action, which took place in Seville in 2012, in order to test the usefulness of the platform for collectives involved in this kind of processes.

\section{Results}

In order to address the three main research questions (the emergence of a new options for urban creativity in the context of austerity; the role of public authorities in these processes; and how architects, planners and policy-makers have learnt from them), this section explores the creative production of collective spaces from two perspectives: whether these initiatives were led by public authorities or by grassroots organisations and the period in which they were created (before and after 2008, when the economic crisis began), analysing the specific role that architects and other creative collectives had in them. The categorisations grassroots versus public initiative and pre-2008 versus post-2008 cannot always be clearly defined. On the one hand, some case initiatives could not be strictly categorised as 'grassroots' or as 'public-authority-led', since they were the result of from joint efforts of a mixed nature. On the other hand, after the credit crunch in early 2008 , it took some time for the austerity measures to be implemented.

\section{Interventions led by grassroots organisations}

The case studies show that grassroots production of collective spaces did not emerge as a reaction to the crisis, but had long existed as a form of activism in the city. The study looked at eight bottom-up processes, actions and spaces promoted by community groups, activists or creative collectives that started before 2008 . These included long-term community-led processes such as allotments -places of continuous resistance-, short term actions to claim collective spaces, and creative spaces that looked for alternative artistic production. 
Processes: The initiative of the community-run allotments at 'Parque de Miraflores' (figure 6) has successfully provided green open spaces and alternative urban agriculture in a peripheral, working-class neighbourhood for more than 30 years of public engagement ${ }^{13}$. This enduring and pioneering community project was unique in Spain when it was created. It has since been followed by other community allotments in Seville such as the 'Huerta del Rey Moro', an ancient orchard within the compact historic centre that was recovered by a group of neighbours as an allotment and space for community activities ${ }^{14}$. Despite some difficulties, both these spaces have received support from the local authority and have been successfully maintained over time.

Other long-term processes, in contrast, have been forms of resistance to topdown interventions, as happened with the 'Alameda de Hercules'. From the 1990s until its municipality-led regeneration in 2006 this large square on the north side of the historic centre symbolized the struggle against the construction of massive transport infrastructures within the city centre of Seville and the fight against gentrification ${ }^{15}$. In 2006, following a participation process led by the municipality, the square was redesigned, limiting vehicular access, providing a larger public space, structures and playgrounds, and also encouraging the proliferation of bars and restaurants, which contributed to its gentrification (see Díaz Parra 2014). While this participation process was taking place, just before the construction works, different groups of activists came together to build an archive of the actions for resistance that had taken place in the square, which led to the publication of El Gran Pollo de la Alameda (Barber et al. $2006)^{16}$.

Actions: Some of the actions included in in the archive mentioned above are examples of short-term actions to claim collective spaces, such as Villardilla by the 
local architect and activist Santiago Cirugeda, a tree-house to protest against the plans for building a car-park in the square.

In fact, Cirugeda's work exemplifies many of the short-term actions demanding collective spaces which are included in this research. This type of intervention, that could be described as 'DIY activism' (see Fabian and Samson, 2016), embraces the case of his 'Kuvas S.C.' project ${ }^{17}$, where he obtained a licence for the temporary placement of a construction-waste tank in the street and to build a playground on top to denounce the lack of spaces for children in the city centre. Similarly, the action of 'Otros Salones Urbanos ${ }^{918}$ shared the same objective and consisted in building a playground on an empty plot in the city centre.

Spaces: The last type of creative intervention identified is the creative space created by an art collective. This is the case of 'Sala de Estar'19 (Living Room), a space promoted by young artists in a flat near the Alameda de Hercules, which aimed to provide an alternative to mainstream artistic production in the city. All these grassroots initiatives (processes, actions and spaces) before 2008 allowed a form of collective contestation that public institutions were not providing.

From 2008, grassroots organisations and creative collectives continued reinventing alternative ways to create collective spaces. Laboratorio Q has chosen three case studies after 2008 to illustrate how the limits between processes, actions and spaces were blurred. These three cases resulting from the foundation of a creative space, were consolidated through creative actions and aimed to start a process of urban change in the city of Seville through the implementation of alternative collective spaces. Acting in the forgotten urban periphery, exploring new ways of work based on sharing resources in the unaffordable city centre, or using cultural production and the support from both 
public and private organisations, these collective experiences evidence both a continuity and an advanced creative approach after the crash of 2008.

Acting in the forgotten periphery: One of the most representative projects of this period is 'La Carpa', an initiative by a theatre company and the architect and activist Santiago Cirugeda, who occupied an empty plot in a peripheral neighbourhood in Seville to create a circus school. More creative collectives joined them, turning ' $\mathrm{La}$ Carpa' ${ }^{20}$ into a creative space, featured in Al Jazeera's series 'Rebel Architecture' (Sousa, 2014), soon after it was dismantled due to disagreements with the municipality ${ }^{21}$. La Carpa was a very ambitious project in which Cirugeda applied his pre-2008 experience in short-term urban actions, which brought a lot of people together, running a great number of cultural events and spectacles.

Exploring new ways of working: Other collectives have also joined forces to build spaces for creative production. This is the case of 'Tramallol'22, a group of professionals from the cultural and creative industries who joined forces to share a space for working, cultural production and events. Tramallol goes beyond the concept of co-working and creates a collaborative space using the traditional craftsman yards in the historic centre of Seville.

Cultural production: After 2008, there have also been projects developed by one or more creative professionals, successfully collaborating with public and private organisations. This is the case of 'Pista Digital'23 (digital track), a project developed by the dancer Salud López and Santiago Cirugeda, which consisted in reusing a bumper cars track as a performance space. Since bumper car tracks can be nomadic constructions that are assembled and dismantled in different places, the objective was to build an itinerant performance space. The project won the 2007 Creativa competition, 
organised by the regional government, and collaborated with both public and private organisations and cultural and creative industries for organising events ${ }^{24}$.

In short, these three projects demonstrate that after 2008, grassroots organisations continued to look for alternative creative and collective places and, in some cases, joined forces with other collectives to make the move from actions to creative spaces. The initiatives identified in the research therefore showed that Seville enjoyed a consistent grassroots tradition of creative appropriation and transformation of urban spaces, which was also continued and expanded during the crisis thanks to the action of professionals and activists with occasional support from public authorities.

\section{Interventions led by public authorities}

In the period between 1996 and 2007, the regional and city governments were also involved in either funding or leading creative initiatives (mainly actions and spaces). This was done through open calls: allowing creative collectives to fund their initiatives, or commissioning artists or cultural agents to run a project, either in the framework of a festival or as an independent project.

Open calls: A successful creative action funded through an open call by the regional government — 'Iniciarte' — addressed in this research is the installation 'M1ML'25 (Figure 7) developed by SinStudio Architecture Office, which took place at the end of 2007, almost coinciding with the crisis, and proposed new ways of interaction between residents, visitors, nature and the public space in the touristic Barrio de Santa Cruz.

Commissioning projects: Another set of actions, in which the public institution boosted the promotion — and not just the funds — of the project through direct commissions to artists, is 'Sevilla $3 \times 2$ '. This project was developed by Italian artist Claudio Zulian and promoted by the Andalusian Centre of Contemporary Art (CAAC), 
highlighting the power of civic engagement in central and peripheral city neighbourhoods. In the context of commissioning an artist within a wider festival, Laboratorio Q identified the case of 'Copilandia'"26 at the 'Festival Sevilla Entre Culturas', which was a floating copyleft paradise on the Guadalquivir River, a boat full of photocopy machines and other copying devices where everything could be copied. Laboratorio Q also compiled a number of cases in which artists have been commissioned to produce creative interventions. Generally, these cases follow a common strategy for city beautification through graffiti. As this research shows, just before the crisis, in 2007, the local water company, EMASESA, and the municipality organised a competition to use graffiti to beautify the water towers on the outskirts of the city $^{27}$.

When the crisis hit Spain in early 2008, there were already some programmes run by public authorities, which continued for a while until more severe austerity measures were implemented. Although some major initiatives were cancelled, they kept organising open calls on urban creativity after 2008. Public institutions continued some of the strategies that they had previously implemented successfully. Indeed, the strategy mentioned earlier, institutionalising a sub-culture such as urban art, continued with other public-led projects involving young creative professionals in the construction of collective spaces.

Open calls: The 'BIACS Transversal' 28 is an example after 2008 of an open call for artists and creative professionals to suggest interventions in collective spaces. The open call was part of the Biennale of Contemporary Art of Seville (BIACS) organised by the CAAC, which is run by the regional government - and it was an initiative of the University of Seville in collaboration with the CAAC, the municipality 
and other institutions. It consisted of a series of artistic actions aiming to activate critical thinking about the urban environment.

Institutionalising urban cultures: The beautification of the city using graffiti continued with three projects: 'Todo Tuyo!'29 (All Yours!), organised by LIPASAMthe municipal cleaning and recycling company- where recycling containers were painted to improve their visibility and use in the city convoking artists through a public competition; 'Sevilla arte para todos' ${ }^{30}$ (Seville art for all), also organised by the municipality and LIPASAM, where international artists were invited to paint the façades of San Pablo neighbourhood in order to changing its appearance and project a renewed identity to their residents and the city; and 'Plaza de Armas'31, a wider project aiming to modernise the image of one of the main historic gates of the city by creating artistic murals over a main bus station and its public space and by enlarging and updating a skate park located in its surroundings. This last project implied the involvement of graffiti artists, architects and the participation of skateboarding collectives in the renovation of the space, bringing life to a marginal sector of the riverfront next to transport infrastructure.

The selection of cases shows that the role of public authorities was to support and promote artistic programmes in public spaces, rather than to foster grassroots organisations. Although this support granted to the arts continued after the 2008 breakdown, it did not last long. Further severe cuts in public services and cultural production, first with the change of the municipal government in May 2011, and later with the shift in the national government in November 2011, meant that the effects of austerity had a stronger impact on the production of collective spaces.

\section{Discussion}

After studying these 19 initiatives of DIY urbanism, resistance, publicly funded 
projects, artistic interventions and collaborative production of collective spaces, and their position in the context of urban development and regeneration in Seville as explained at the beginning of this paper, this section will address the three research questions outlined in the introduction.

The first question explores the scope of the alternative options for the production of creative spaces in the context of austerity which have appeared. As the case studies show, grassroots organisations and creative collectives have been producing alternative collective spaces and contesting certain practices of top-down urbanism since long before the 2008 crisis. In some cases, differences can be appreciated between pre-2008 and post-2008 grassroots transformations of collective spaces, although there is not enough evidence to find a common pattern.

On the one hand, certain kinds of guerrilla actions of the early 2000 s, such as Cirugeda's 'Kuvas S.C.' and 'Otros Salones Urbanos', moved towards more ambitious proposals after 2008, requiring the collaboration of different activists and collectives, including 'La Carpa'. The aim of La Carpa was not just to make a claim but also to provide an alternative collective space. In fact, in the interview, Cirugeda was sceptical about the impact of his earlier interventions, which he believed did not empower local people to take similar initiatives, and advocated for collective self-built projects in collaboration with others ${ }^{32}$. However, there is evidence of projects with ambitious objectives started before 2008 that were achieved thanks to the collaboration between different individuals, such as the allotments in Parque Miraflores and Huerta del Rey Moro. These still remain active at the time of writing, demonstrating the resilience of grassroots organisations in the creative appropriation of urban spaces.

This research also identified a change in the location of these initiatives. Most of the initiatives studied are found within the historic city centre, and only a few are in 
other parts of the city or its periphery. Before 2008, many of the actions in the northern part of the historic centre arose as a form of resistance against gentrification and major regeneration schemes, or demands for more public spaces. Other reasons for this may be the greater media impact of interventions in the historic centre, and the growing concern about heritage conservation, with civic engagement seen to be one of the keys to the sustainable management of the transformation of the historic city (Bandarin and Van Oers, 2012). However, the grassroots interventions studied after 2008 are not in visible locations within the historic centre. 'La Carpa' was in an empty plot next to a peripheral neighbourhood, 'Pista Digital' was located in an abandoned venue within the Expo 1992 site and then moved to another municipality in the Seville Metropolitan Area while Tramallol is in the city centre, albeit in an area less exposed to gentrification. In fact, the meeting of the Spanish network of collectives in December 2012 highlighted the importance of these bottom-up spaces in the periphery. This could mean that these projects prefer to remain hidden from the gentrification processes of the city to build alternative spaces. However, it does not mean that peripheral activism is something new, as the allotments in Parque Miraflores - the grassroots project with a longer lifedemonstrate. Recent literature has highlighted the historic relevance of peripheral urban civic organisation in city development (Talen, 2015).

Although grassroots interventions may not have undergone drastic changes after the crisis, as some conversations with the interviewees revealed, they are of greater interest to academics, architects, and also public authorities. Ultimately, this leads to changes in the definitions of creative production of collective spaces. These changes in the understanding of creativity can be explained by addressing the second and third research questions: the role of public authorities and how architects and planners learn from these processes. 
As explained initially, when austerity measures were implemented, public authorities had carried out large budget regeneration schemes, such as the construction of Plaza Encarnación, started in 2005 and completed in 2011 which is the most extreme example of public expenditure. The last period of the construction of the square coincided with cuts in public investment and, soon after its inauguration, the square became the backdrop to the anti-austerity protests of the 15-M movement. In addition to large-scale regeneration schemes, public institutions have been involved in smallerscale actions both before and after 2008, with varying degrees of collaboration with the civil society, activists, community groups and creative collectives, although the relationship between public institutions and grassroots organisations has been problematic on many occasions.

As seen in the case studies, the role of public authorities has been to fund small interventions in public spaces, through calls for projects, commissions for specific projects on community engagement, use of sub-cultures such as graffiti to beautify the city and create a sense of place, and trying to involve artists and collectives in regeneration processes.

Some of these publicly funded initiatives took their inspiration from bottom-up, deregulated practices, thus reflecting the interest of public authorities in the power of small-scale actions and community engagement, even though this followed a mostly aesthetic, artistic approach. In other cases, the involvement of public authorities in civic engagement process has taken the form of temporary free leases of public land to community organisations in charge of managing the development of collective activities. In some cases, such as the allotments in Parque Miraflores and Huerto del Rey Moro, the community has managed to reach long-term lease agreements with the local authorities. However, in others, such as 'La Carpa', poor communication between 
local authorities and collectives - who denounced a lack of interest in the project on the part of the municipality_-led to the agreement being terminated and the place dismantled ${ }^{33}$.

One of the main topics of discussion is the relationship between the spontaneous initiatives recorded and the institutional urban planning practices. Despite evidence of the growing interest of local authorities in civic engagement processes, some interviewees denounced the lack of cooperation from public authorities in their projects $^{34}$. The distance between both positions is representative of the current crisis in public policies, especially in terms of the regeneration of the urban environment. An ideal scenario would be a compromise halfway, with bottom-up initiatives paving the way for the renovation of urban planning, which should adopt more open, indeterminate stances, in order to meet real-time demands from the citizens (Talen, 2015). This has happened in some cases where it has been possible for a public institution and a community organisation to reach an agreement. However, the case studies and public engagement events developed as part of the Laboratorio Q research project showed a lack of confidence in the public administration, which has long acted from the top down and continues to implement bureaucratic procedures in order to accomplish creative actions.

Nevertheless, grassroots practices have attracted the attention of former topdown stakeholders. This is the case of the Andalusian Ministry of Public Works and Territorial Planning, currently supporting La Ciudad Amable, a project for the renovation of the urban environment in the region, mainly inspired by DIY initiatives, which was granted a Best Practice award by UN-Habitat in 2014. Institutional planning has adopted practices including urban farming, found in Parque Miraflores or Huerta del Rey Moro. More recently, anti-eviction policies have been incorporated by local 
governments in Spain in response to the demands of the 'Plataforma de Afectados por la Hipoteca' (Platform of those Affected by Mortgage). However, an ideal of autonomy and a need for detachment from the discourses of power still prevail in the sphere of the commons. As discussed above, although local authorities appear to be incorporating some of the ideas from bottom-up interventions into their policies, even adopting similar discourses to civic projects, there are still tensions and difficulties in cooperation between grassroots organisations and public authorities in the production of collective spaces.

Lastly, the third question addresses how architecture and planning — as well as their academic research - are 'learning' from these grassroots experiences. Academic interest in 'DIY urbanism' has increased, as can be seen in the 2014 special issue Vol. 7 No. 4 of this journal (see Finn 2014b). It has also become a reference for architects and urban planners, who see new opportunities for transforming the built environment and achieving considerable impact with limited resources.

Our interviewees included five architects: Paula Álvarez, Daniel Yabar, Marta Pelegrín, Bernardo Gómez and Santiago Cirugeda. Paula Álvarez is the co-author of one of the actions studied: the installation in the public space M1ML, which demonstrates an engagement with the creative transformation of the public space. Paula Álvarez is also the editor of the book Arquitecturas Colectivas (Cirugeda, 2010), which follows Cirugeda's installation of containers in different locations. In the interview, she explains that, in an investigation on 'New models of intervention in the public space' she and José M. Galán carried out for the Department of Public Works of the Government of Andalusia, they explored how architects could incorporate a 'distributed creative' into professional practice ${ }^{35}$. 
Daniel Yabar is an architect specialising in skateparks and author of the project for the rehabilitation of the Plaza de Armas Skatepark, a municipality-led project which included new skatepark facilities and a transformation of the public space around the bus station with the participation of graffiti artists. Marta Pelegrín, co-founder of Mediomundo architects, highlighted the importance of researching empty places in the city in order to identify them, as well as their potential to be collectively claimed by the citizens $^{36}$, thus providing evidence of the overlap between professional practice and research in the creative transformation of the city. The architect Bernardo Gómez, along with Santi Barber and other creative practitioners, explains how a group of people came together to find new ways of working by transforming an industrial shed in the historic centre into a shared space, Tramallol, which is runs as a cooperative, in response to a need for affordable workspaces in the historic centre ${ }^{37}$. Gómez runs his architectural practice from this collective space which he has co-initiated with a group of creative practitioners, sharing resources, interacting and organising activities. This case provides evidence on this hybrid role of cultural agent, promoter of collective spaces and architect. The architect Santiago Cirugeda is involved in many of the actions detailed in this paper and is internationally known as an example of architect-activist who looks for gaps in legislation in order to occupy empty pieces of land for collective use ${ }^{38}$.

In addition to the interviews, the researchers engaged in the organisation of the annual event 'Arquitecturas Colectivas' (Collective Architectures), which took place in Seville during the fieldwork in December 2012. This is a grassroots event organised by 'collectives', groups of architects working on the frontier between architecture and activism and exploring the production of collective spaces. The Collective Architectures network demonstrates the hybrid character of architect-activist emerging as a way to work collaboratively and engage with social movements. It is rather telling that 
architectural critic Luis Fernández-Galiano, co-curator in 2006 of the MoMA exhibition “On-Site: New Architecture in Spain” showing the splendour of Spanish architecture, edited an issue of the Spanish journal Arquitectura Viva entitled 'Colectivos Españoles: Nuevas formas de trabajo: redes y plataformas' (Fernández-Galiano 2012) (Spanish Collectives: New forms of working: networks and platform), in which he compiles creative collectives that are looking at alternative architectural practices. This growing interest in grassroots collectives was received with scepticism by some of the activists interviewed in our project.

In short, it can be argued that architects are carrying out research on collective actions and trying to incorporate this knowledge in their professional practice. From this research-led practice, they are engaging in creative practices for producing public spaces. In addition to this, the Collective Architecture network evidences the emergence of hybrid architecture-activism collectives, which engages with social movements for the production of collective spaces.

\section{Limitations and further research}

This paper presents the results of the first research project carried out by Laboratorio Q, whose fieldwork finished in December 2012, although it has included in the discussion some of the events that took place after completion of the fieldwork. However, this paper has not included the 'municipalist' initiatives that managed to win the 2015 local elections in Spain, as was the case in Madrid or Barcelona, among others. In these cases, independent groups of people, which included activists and academics, managed to put together a candidature for the local elections and win the municipality. This phenomenon is not the topic of this paper and its impact on the production of collective spaces must be studied in further research. 
From December 2012 until the time of writing, the Laboratorio Q project has been under constant development, addressing the limitations identified in the first phase of the project. These limitations come from the methodology for engaging participants in the production of knowledge. One of the main challenges of Laboratorio Q was to engage activists and community groups in the production of knowledge by collecting their testimonies, organising public engagement events involving grassroots organisations, and encouraging people to use the participatory mapping tool to build collective knowledge. While the collection of testimonies through recorded interviews succeeded in involving the participants in the production of knowledge, the public engagement events brought out some tensions as to how certain agents and groups see their work represented in the platform, sharing the space with other top-down initiatives developed by local authorities. Furthermore, public and academic institutions are frequently associated with fruitless top-down urban actions, so that these organisations are commonly seen as unreliable_ _ administrative constraints, lack of funding and social support, broken promises - by citizens and collectives involved in these processes. This perception could have worked against the project, preventing these agents from becoming involved in the platform. Due to this, this experience leads to the conclusion that, when research involves collaboration with activists and community groups, it is necessary to develop specific methodologies to facilitate dialogue. The participation on the mapping tool has not been as successful as expected, for two possible reasons: the aforementioned issues in the public engagement methodology, and also the lack of funding for the project, which was affected by the cuts in academic research. 


\section{Conclusions}

The paper has explored the redefinition of urban creativity in times of austerity in the context of Seville, which had not been addressed before in academic literature. In this context, it has explored the role of public authorities in the production of collective spaces, and how architects and planners are learning from grassroots initiatives. This paper contributes to the discussion on the emergence of creative responses to austerity in Southern European cities. Arampatzi has identified 'urban solidarity spaces' (Arampatzi 2017, 2155) in Athens as 'creative alternatives to austerity' (Arampatzi $2017,2159)$ that emerge from the bottom-up. This urban creativity departs from the idea of creativity for attracting talent and economic development that Florida (2002) advocated for at the turn of the 21 st century.

The present study on Seville concludes that bottom-up initiatives existed long before the 2008 crisis, although there is some evidence of a trend towards more collaboration between different collectives and interest in peripheral places. However, although these initiatives have not undergone drastic changes, this paper has identified a change of approach in how public authorities produce public spaces. In the last part of the period of study they abandoned high public expenditure projects and began to look at ways to get inspiration from grassroots interventions. However, inspiration in bottomup initiatives does not mean collaboration in many cases, and there are still many tensions between activists, community groups, creative collectives, and public institutions. These tensions come from the lack of support towards the projects, the lack of confidence in public institutions, and also the fear of institutionalising a grassroots movement. The paper has also identified how, in times of austerity, bottom-up interventions and DIY urbanism have become very popular amongst academics, architectural and planning practice and theory. Activists and community groups are 
aware of this situation and are also sceptical about it. They struggle to keep their projects alive, with very little or no funding at all, and lack of support from public institutions, while, at the same time they receive constant requests from media, specialised magazines, academics, art biennales and others to talk about their initiative. One of the lessons learnt from the Laboratorio Q project is that academics should take this into account when designing a research methodology.

\section{References}

Alanís Arroyo, Antonio, María F. Carrascal Pérez, Plácido González Martínez, Pablo Sendra Fernández. 2015. “Un mapa de relatos urbanos. Laboratório Q de lugares de creatividad urbana." Revista dearq 16: 44-59.

Álvarez Benítez, Paula. 2005. "Sevilla Ciudad: lugares de imágenes compartidas, de Claudio Zulian. Inaugurar un mundo.” Ábaco 44-45: 133-139.

Arampatzi, Athina. 2017. "The spatiality of counter-austerity politics in Athens, Greece: Emergent 'urban solidarity spaces'." Urban Studies. Published online: doi: $10.1177 / 0042098016629311$

Bandarin, Francesco; Ron Van Oers. 2012. The Historic Urban Landscape. Managing Heritage in an Urban Century. Oxford: Blackwell.

Barba, Eduardo. 2012. "La factura final de las «setas» es de 102 millones, el doble de lo presupuestado." ABC de Sevilla. May 8. Accessed 25 August 2017: http://sevilla.abc.es/20120508/sevilla/sevi-factura-final-setas-millones201205072258.html.

Barber, Santiago, Victoria Frensel, Maria J Romero. 2006. Como nació, creció y se resiste a ser comido el gran pollo de la Alameda: una docena de años de lucha social en el barrio de la Alameda, Sevilla. Sevilla: La Fuga Librerías.

Brey, Raul, Jose I. Castillo-Manzano, Mercedes Castro-Nuno, Lourdes LopezValpuesta, Manuel Marchena-Gomez, Antonio Sanchez-Braza. 2017. "Is the widespread use of urban land for cycling promotion policies cost effective? A Cost-Benefit Analysis of the case of Seville". Land Use Policy, 63" 130 - 139. doi: 10.1016/j.landusepol.2017.01.007

Cirugeda, Santiago. 2010. Arquitecturas colectivas. Camiones, contenedores y colectivos. Sevilla: Vibok Works. 
United Nations/UNDP/UNESCO, 2013. Creative Economy Report. 2013 Special Edition. Widening Local Development Pathways. Accessed 15 September 2016: http://www.unesco.org/culture/pdf/creative-economy-report-2013.pdf

Díaz, Ibán. 2010. Sevilla, cuestión de clase. Una Geografía Social de la Ciudad. Sevilla: Atrapasueños Editorial.

Díaz Parra, Ibán. 2014. ¿Gentrificación o barbarie? Disciplinamiento y transformación social del barrio de la Alameda de Sevilla. Sevilla: Atrapasueños Editorial.

Fabian, Louise and Kristine Samson. 2016. "Claiming participation - a comparative analysis of DIY urbanism in Denmark." Journal of Urbanism: International Research on Placemaking and Urban Sustainability, 9 (2): 166-184. doi: $10.1080 / 17549175.2015 .1056207$

Fernádez-Galiano (ed.). 2012. Special Issue 'Colectivos Españoles: Nuevas formas de trabajo: redes y plataformas'. Arquitectura Viva, 145.

Finn, Donovan. 2014a. "DIY urbanism: implications for cities." Journal of Urbanism: International Research on Placemaking and Urban Sustainability, 7 (4): 381398. doi: 10.1080/17549175.2014.891149

Finn, Donovan. 2014b. "Introduction to the special issue on DIY urbanism." Journal of Urbanism: International Research on Placemaking and Urban Sustainability, 7 (4): 331 - 332. doi: 10.1080/17549175.2014.959154

Florida, Richard. 2002. The rise of the creative class: and how it's transforming work, leisure, community and everyday life. New York: Basic Books.

Garea, Fernando. 2012. "El PP ratifica sin apoyos en el Congreso el mayor recorte al Estado de bienestar.” El País. May 17. Accessed 16 May 2016: http://politica.elpais.com/politica/2012/05/17/actualidad/1337245957_222091.ht $\underline{\mathrm{ml}}$

González, Plácido, Pablo Sendra, María Carrascal, Carlos García, Antonio Alanís, Alfonso Guajardo. 2017. "Laboratorio Q Sevilla: una investigación sobre creatividad urbana”. In Sendra, Pablo, Maria Joao Pita, CivicWise (Eds.) Civic Practices. Sevilla: Lugadero, $178-181$.

Harvey, David. 1989. "From managerialism to entrepreneurialism: the transformation of urban governance in late capitalism." Gleografiska Annaler Series B Human Geography 71(1): 3-17.

Landry, Charles. 2000. The Creative City: a toolkit for urban innovators. $2^{\mathrm{a}}$ Ed., 2008. London: Earthscan. 
Instituto Nacional de Estadística. 2013. Encuesta de Población Activa (EPA) Cuarto trimestre de 2013. Accessed 15 September 2016: http://www.ine.es/daco/daco42/daco4211/epa0413.pdf

Lydon, Mike, Anthony Garcia. 2012. Tactical urbanism: short-term actions for longterm chang. Washington: Island Press.

McKee, Kim. 2015. "An Introduction to the Special Issue - The Big Society, Localism and Housing Policy: Recasting State-Citizen Relations in an Age of Austerity." Housing, Theory and Society, 32(1): 1-8. doi: $10.1080 / 14036096.2014 .947174$

Pelegrín Rodríguez, Marta, Pérez Blanco, Fernando. 2015. Arquitectura dispuesta: Preposiciones cotidianas. Sevilla: Universidad de Sevilla.

Rincón, Reyes. 2010. “Los problemas crecen bajo las 'setas'.” El País. 25 July. Accessed 25 August 2017: https://elpais.com/diario/2010/07/25/andalucia/1280010124_850215.html.

Rincón, Reyes. "Sevilla esquiva el castigo de la Unesco por el rascacielos diseñado por César Pelli.” El País. 27 June. Accessed 25 August 2017: https://elpais.com/ccaa/2012/06/27/andalucia/1340798497_874691.html.

Riley, Terence, Luis Fernández-Galiano. 2006. On Site: New Architecture in Spain. New York: The Museum of Modern Art.

Sousa, Ana Naomi de. 2014. 'Guerrilla Architect' in 'Rebel Architecture' series. Aljazeera. August 19. Accessed 31 August 2017: http://www.aljazeera.com/programmes/rebelarchitecture/2014/06/spainguerrilla-architect-201462993348959830.html.

Talen, Emily. 2015. "Do it yourself urbanism: a history." Journal of Planning History 14(2): 135-148.

Valdés Aragonés, Isabel. 2014. “Sevilla, paraíso de dos ruedas.” El País. May 11. Accessed 25 August 2017: https://elpais.com/elpais/2014/05/07/eps/1399465309_221018.html. 


\section{Figure captions}

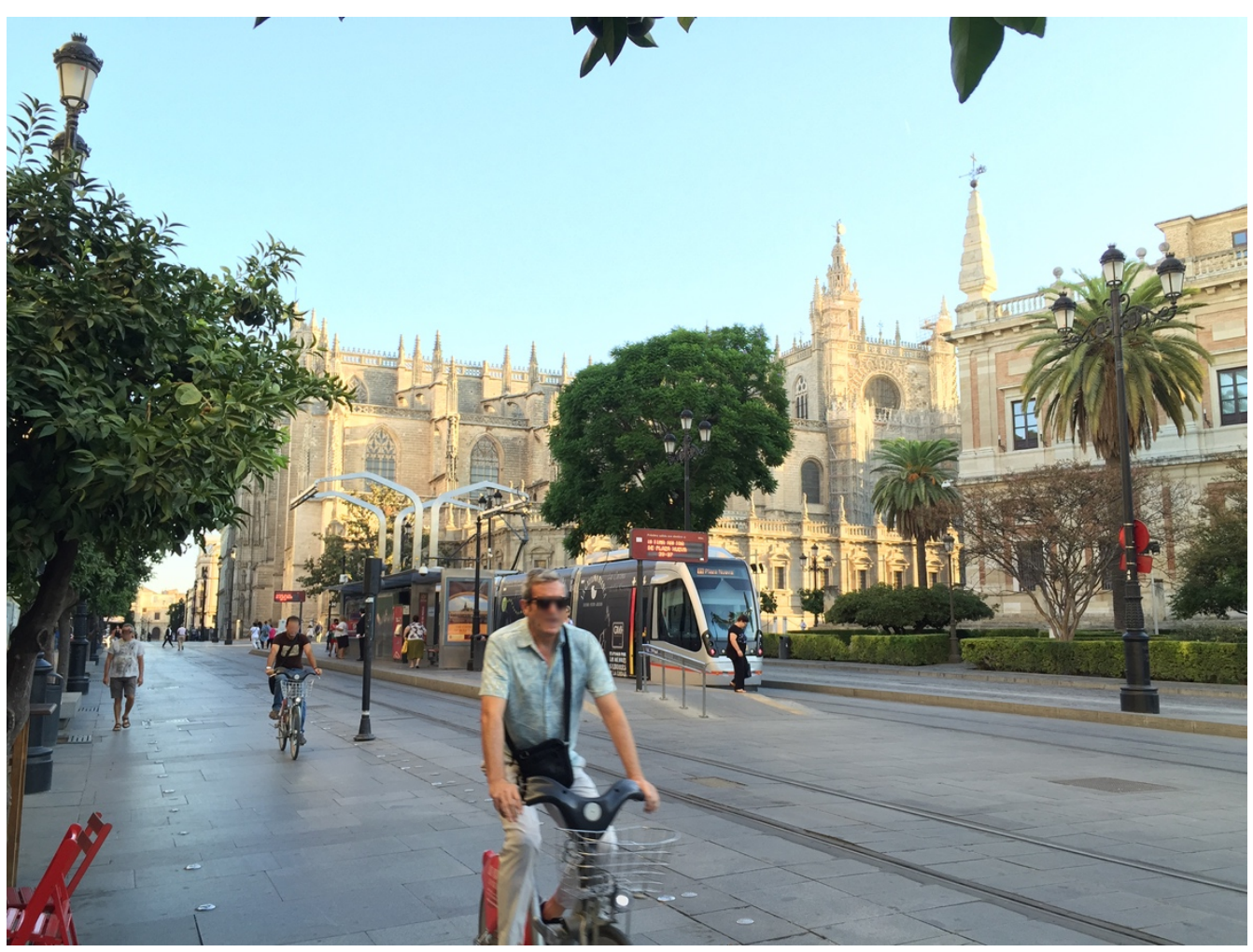

Figure 1. Pedestrianised Constitución Avenue and tram (metrocentro). Photograph by author.

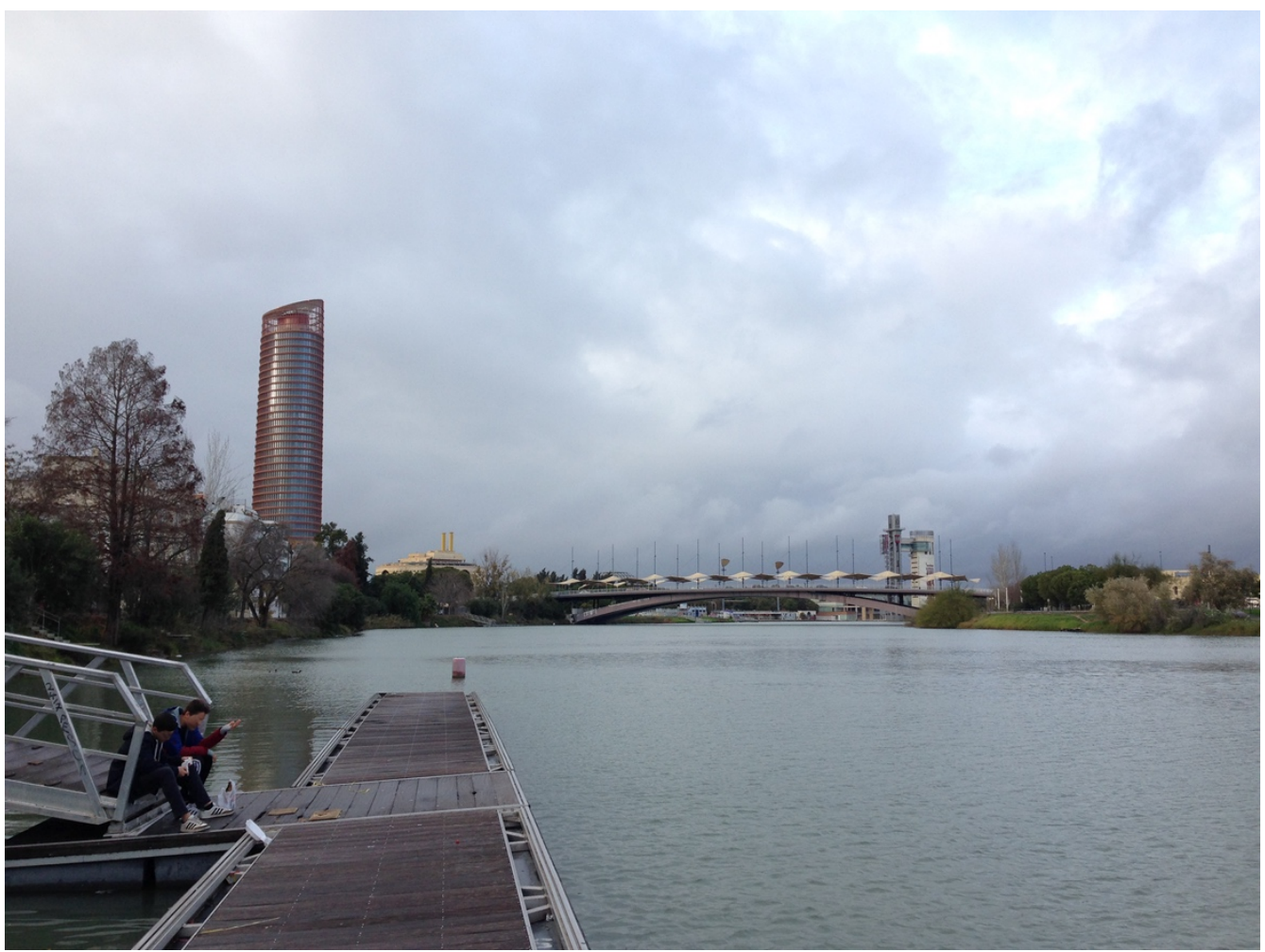

Figure 2. View of "Torre Sevilla" from the Guadalquivir River, photograph by author. 


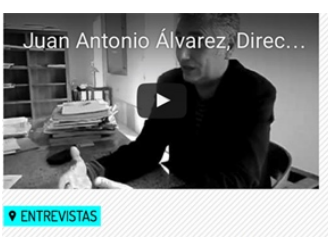

Entrevista a Juan Antonio Álvarez. Director del CAAC

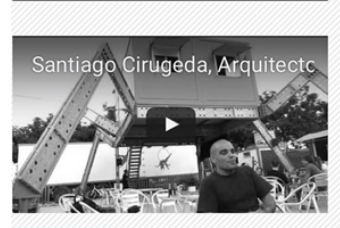

PENTREVISTAS

Entrevista a Santiago Cirugeda, Arquitecto

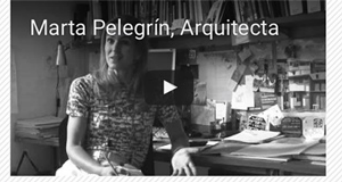

- ENTREVISTAS

Entrevista a Marta Pelegrin, Arquitecta

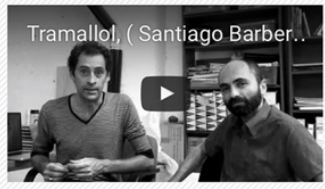

P ENTREVISTAS

Entrevista a Tramallol, Santiago Barber y Bernardo Gómez

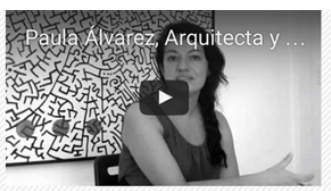

PENTREVITAS

Entrevista a Paula Álvarez.

Arquitecta y editora

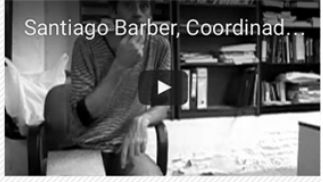

- ENTREVISTAS

Entrevista a Santiago Barber, coordinador EGPA

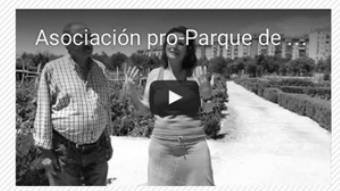

- ENTREVISTAS

Entrevista Asociación pro-Parque de Miraflores

Figure 3. Selection of clips from interviews to local agents. Source:

www.laboratorioq.com.

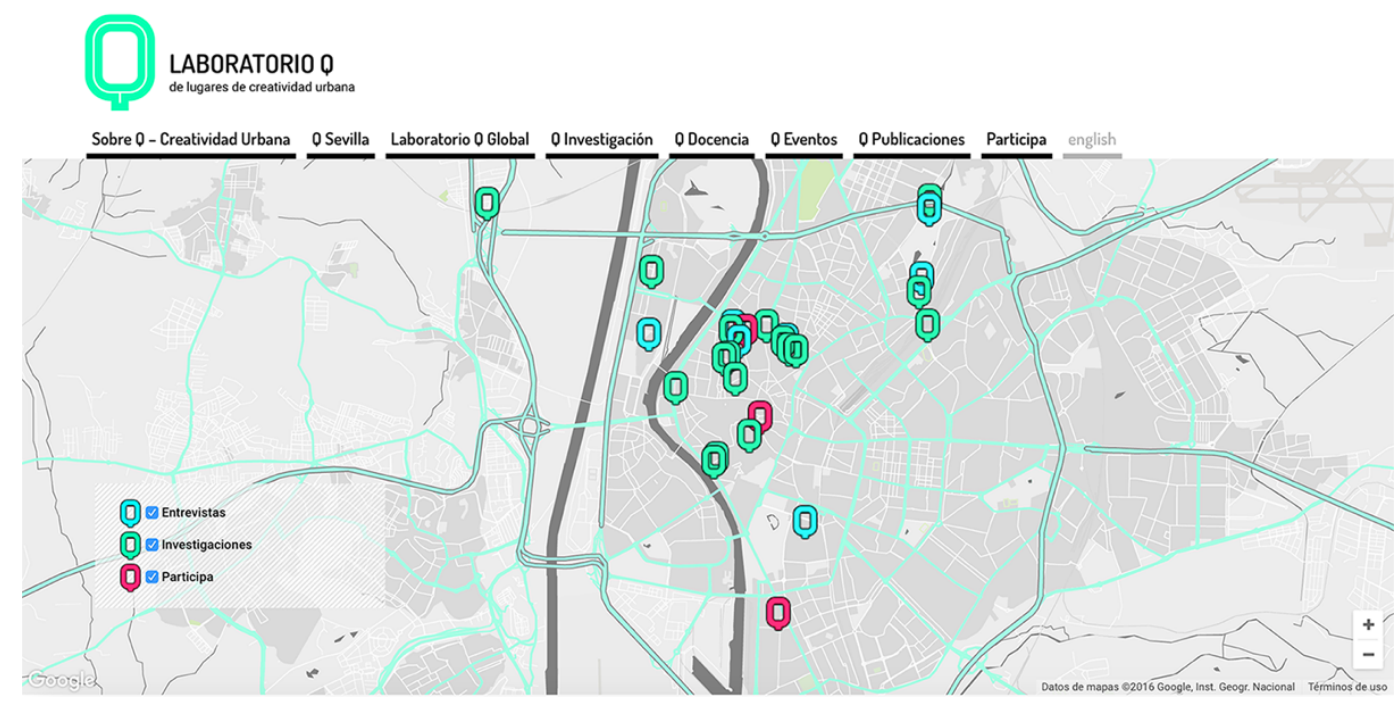

Figure 4. Screenshot of Q Places mapped in Laboratorio Q Seville. Source: www.laboratorioq.com. 


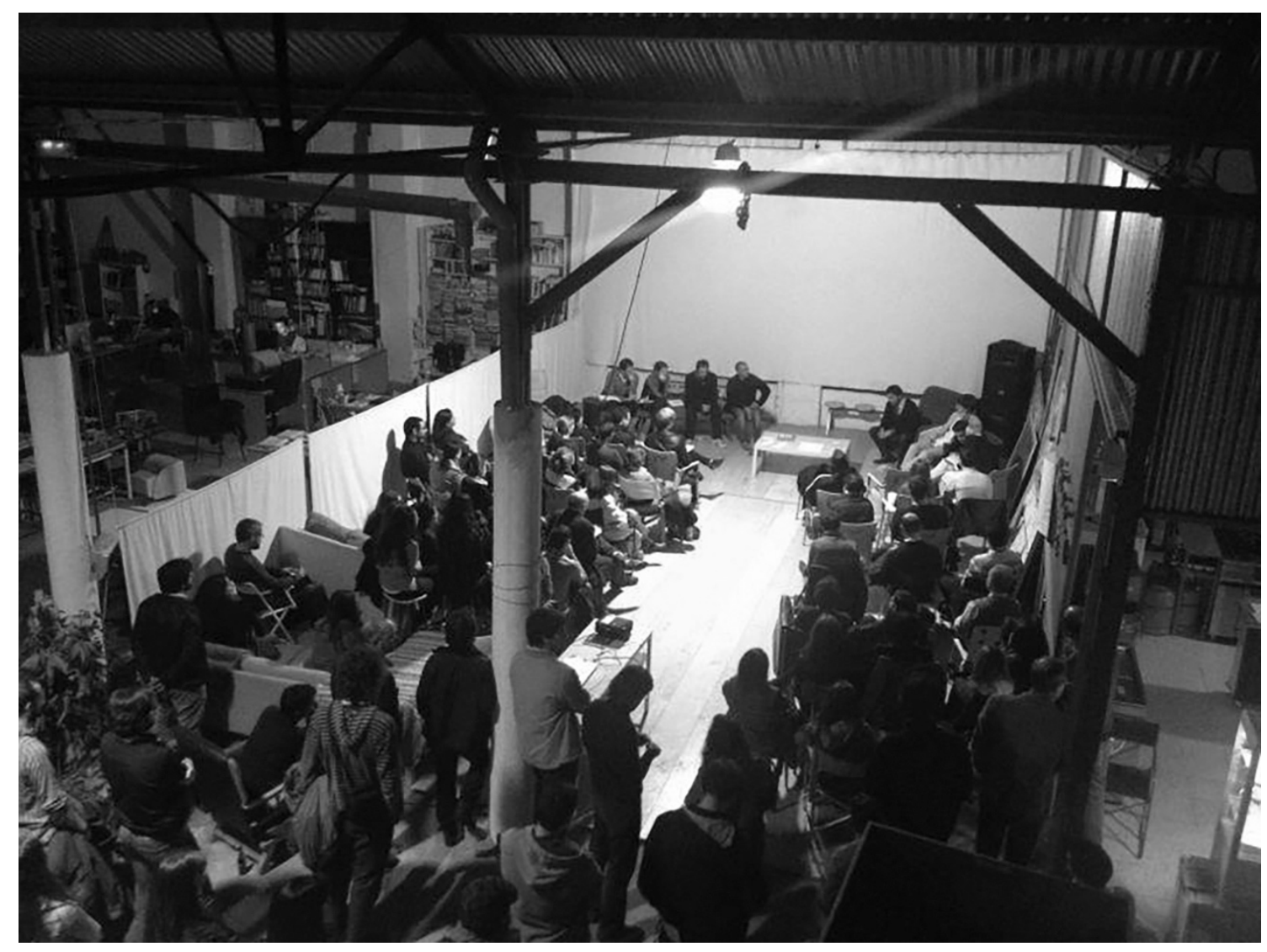

Figure 5. Public engagement event in Tramallol, November 2012, Seville. Photograph by author.

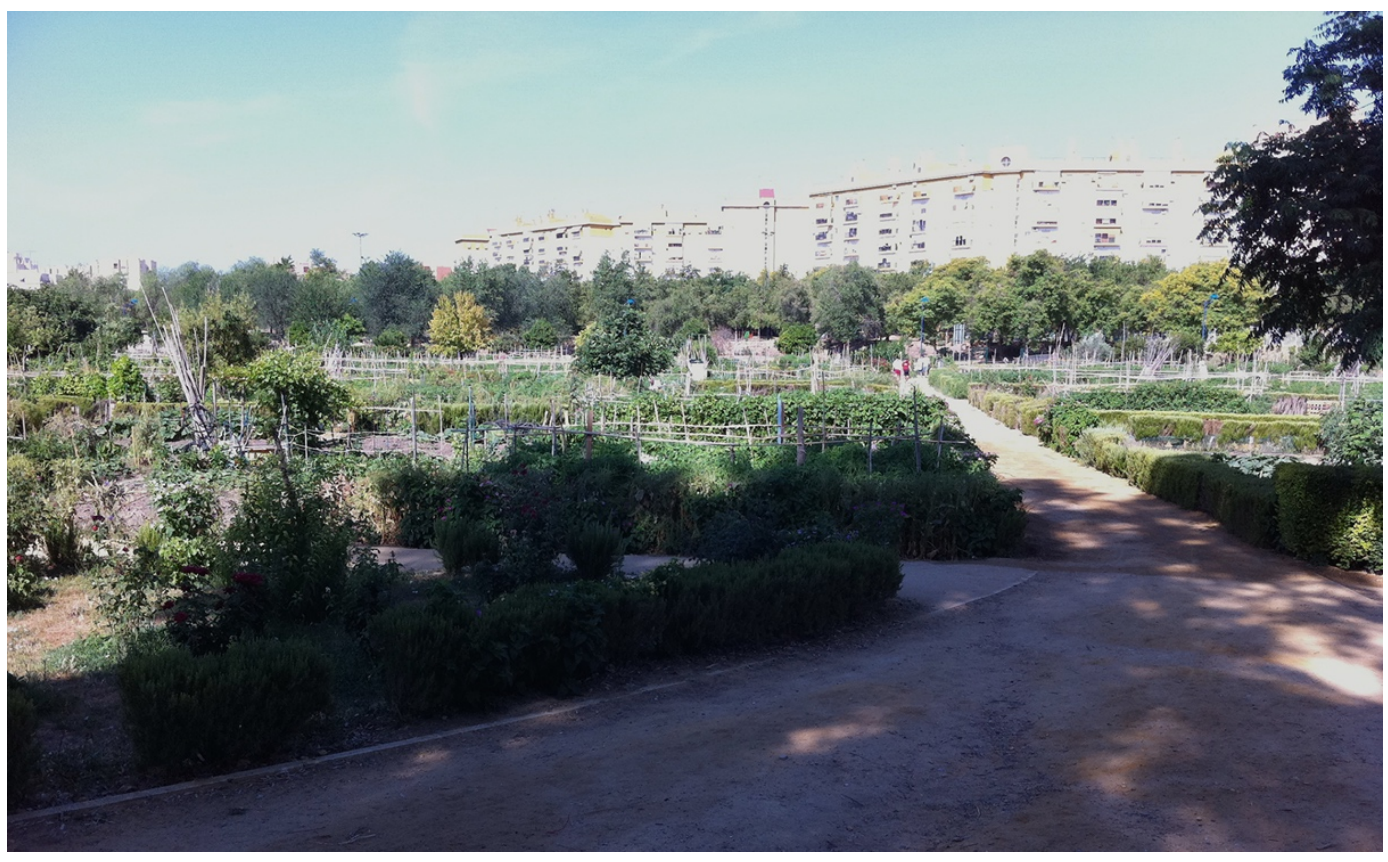

Figure 6. Parque Miraflores, Seville. Photograph by the author. 


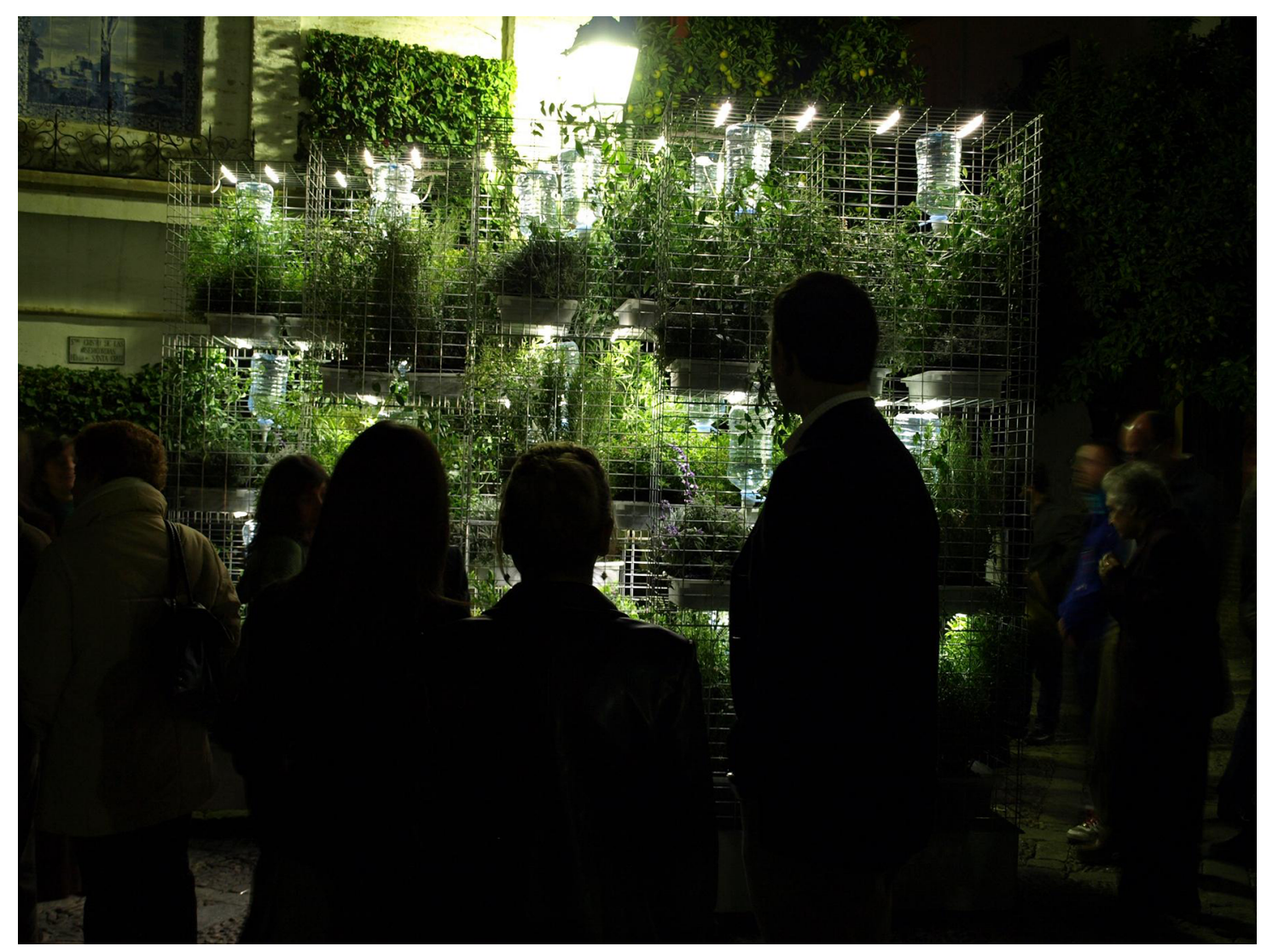

Figure 7. M1ML. Photograph by sin|studio (CC BY 2.0).

\section{Notes}

1 Data from the 2014 census, published by the Instituto Nacional de Estadística.

2 Paradoxically, the Plaza de la Encarnación became the place for the anti-austerity movement 15-M in May 2011, soon after its inauguration.

3 6.278.200 unemployed in the beginning of 2013. Source: Instituto Nacional de Estadística.

4 41,2\% between 2007 and 2014. Source: TINSA, Tasaciones Inmobiliarias.

5 Source: Caixabank, 2016.

6 Source: Junta de Andalucía.

7 Source: Junta de Andalucía.

8 It included people that had been involved in the different creative actions, spaces and processes included in this research. A full list of interviewees can be found here: http://www.laboratorioq.com/han-participado/

9 In most of the cases they were carried out on site, except some cases that were done by Skype, phone calls and email exchange. 
10 The participants included the activist and academics, architects, artists, art critics and curators. A full list of interviewees can be found here: http://www.laboratorioq.com/hanparticipado/ Ibán Díaz, involved in the defence of housing rights (Díaz 2010), who supported this research in identifying processes developed by community groups. Representatives of the creative community in Seville were also interviewed: Marta Pelegrín, architect and academic that studies the potentiality of the urban voids of the city (Pelegrín Rodríguez and Pérez Blanco, 2015); Claudio Zulián, artist that worked on a project with community groups in three neighbourhoods in Seville (Álvarez Benítez, 2005); Juan Bosco Díaz-Urmeneta, art critic, who provided support in identifying artistic actions in the city; Esther Regueira, art curator, who identified projects developed by collective of artists in the public space; and Paula Álvarez, publisher and disseminator of alternative architectural and urban practices (see Cirugeda 2010) and co-author of the installation M1ML.

11 This included the director of the Andalusian Centre of Contemporary Art (CAAC) and responsible of the Seville Contemporary Art Biennale (BIACS); and the former director of the Institute of Culture and Arts of the Municipality of Seville (ICAS) and staff of the municipal cleaning and recycling company (Lipasam), who had promoted a graffiti project among local artists consisting on painting the recycling containers.

12 In the latest update of the website in 2016, the category 'suggested' has been renamed as 'participate'.

13 See http://www.laboratorioq.com/global/laboratorioqsevilla/proceso-vecinal-parquemiraflores/, accessed 30 August 2017. Source: Interview with the Asociación Pro-Parque Miraflores.

14 See http://www.laboratorioq.com/global/laboratorioqsevilla/huerta-del-rey-moro/, accessed 30 August 2017. Source: Interview with Ibán Díaz.

15 See http://www.laboratorioq.com/global/laboratorioqsevilla/alameda-de-hercules-unespacio-donde-la-creatividad-habita/, accessed 30 August 2017. Source: interviews with Santiago Cirugeda; Iban Díaz; Santiago Barber, coordinator of 'El Gran Pollo de la Alameda'.

16 See more details at http://www.laboratorioq.com/global/laboratorioqsevilla/el-gran-pollo-dela-alameda-la-historia-contada-por-sus-protagonistas/, accessed 30 August 2017. Source: Interview with Santiago Barber.

17 See http://www.laboratorioq.com/global/laboratorioqsevilla/kuvas-s-c-cubas-contenedores/, accessed 30 August 2017. Source: Interview with Santiago Cirugeda.

18 See http://www.laboratorioq.com/global/laboratorioqsevilla/otros-salones-urbanosordenacion-y-ocupacion-temporal-de-solares-recetas-urbanas/, accessed 30 August 2017. Source: Interview with Santiago Cirugeda. 
19 See http://www.laboratorioq.com/global/laboratorioqsevilla/sala-de-estar/, accessed 30 August 2017. Source: Interviews with Juan Bosco Díaz-Urmeneta, Professor of Art Theory and Aesthetics; Esther Regueira, Curator; and the Director of CAAC.

20 See http://www.laboratorioq.com/global/laboratorioqsevilla/la-carpa/, accessed 31 August 2017. Source: interview with Santiago Cirugeda.

$21 \mathrm{https}: /$ lacarpasevilla.wordpress.com/2014/05/03/comunicado-de-la-carpa-espacio-artistico/, accessed 04 September 2017.

22 See http://www.laboratorioq.com/global/laboratorioqsevilla/pasaje-mallol-y-castellar/, accessed 31 August 2017. Source: Interview with Santiago Barber and Bernardo Gómez, Tramallol.

23 See http://www.laboratorioq.com/global/laboratorioqsevilla/pista-digital/, accessed 31 August 2017. Source: interview with Santiago Cirugeda.

24 Source:

http://enlugardecreacion.org/descargas/Plataforma_portatil_para_la_Danza_y_la_Cultura. _PistaDigital/Dossier_Pista_Digital-comercial.pdf, accessed 31 August 2017.

25 See http://www.laboratorioq.com/global/laboratorioqsevilla/m1ml/, accessed 30 August 2017.

26 See http://www.laboratorioq.com/global/laboratorioqsevilla/copylandia/, accessed 31 August 2017. Source: interview Esther Regueira.

27 See http://www.laboratorioq.com/global/laboratorioqsevilla/torres-de-emasesa/, accessed 31 August 2017.

28 See http://www.laboratorioq.com/global/laboratorioqsevilla/el-arte-urbano-de-la-biacs3descubre-los-espacios-intermedios-de-la-transversal/, accessed 31 August 2017. Source: interviews the former director of ICAS $(2006-2011)$ and the director of CAAC.

29 See http://www.laboratorioq.com/global/laboratorioqsevilla/todo-tuyo/, accessed 31 August 2017. Source: interview staff from LIPASAM.

30 See http://www.laboratorioq.com/global/laboratorioqsevilla/sevilla-arte-para-todos/, accessed 31 August 2017. Source: interviews with former director of ICAS (2006-2011) and staff from LIPASAM.

$31 \mathrm{See}$ http://www.laboratorioq.com/global/laboratorioqsevilla/enviando-una-nueva-postal-elparque-redibujado-de-plaza-de-armas/, accessed 31 August 2017. Source: interviews with former director of ICAS (2006-2011); Daniel Yabar, architect; Juanjo Laguna, director Microlibre Producciones.

32 See interview with Santiago Cirugeda: http://www.laboratorioq.com/global/laboratorioqsevilla/entrevista-a-santiago-cirugeda/, accessed 1 September 2017. 
33 https:/lacarpasevilla.wordpress.com/2014/05/03/comunicado-de-la-carpa-espacio-artistico/, accessed 04 September 2017.

34 See interview with Santiago Cirugeda:

http://www.laboratorioq.com/global/laboratorioqsevilla/entrevista-a-santiago-cirugeda/, accessed 1 September 2017.

${ }^{35}$ See interview with Paula Álvarez:

http://www.laboratorioq.com/global/laboratorioqsevilla/entrevista-a-paula-alvarezarquitecta-y-editora/, accessed 11 May 2018. See also http://www.alvarezpaula.com/es/10nm-inicio.html, accessed 11 May 2018.

${ }^{36}$ See interview with Marta Pelegrín:

http://www.laboratorioq.com/global/laboratorioqsevilla/entrevista-a-marta-pelegrinarquitecta/, accessed 11 May 2018. (See also Pelegrín Rodríguez and Pérez Blanco, 2015).

${ }^{37}$ See interview with Bernardo Gómez and Santi Barber, Tramallol: http://www.laboratorioq.com/global/laboratorioqsevilla/entrevista-a-tramallol-santiagobarber-y-bernardo-gomez/, accessed 11 May 2018.

${ }^{38}$ See interview with Santiago Cirugeda:

http://www.laboratorioq.com/global/laboratorioqsevilla/entrevista-a-santiago-cirugeda/, accessed 11 May 2018. 